\title{
Research on Application of Multimedia Technology in Walking Race Teaching
}

\author{
Lan Zhou \\ Northwest University, Xian 710069, China
}

Keywords: Multimedia Technology; Walking Race Teaching; Application; Research

\begin{abstract}
The application of multimedia technology can bring a lot of unexpected results for teaching. The application of multimedia technology has the same important significance in walking race teaching. With the problems existed in walking race teaching as the starting point, this article provide a summary of the application of multimedia technology in walking race teaching and prove the means of applying this modern technology as supplementary means of teaching in order to provide help for changing the status of the current walking race teaching.

Entering the 21 st century, relatively obvious changes have taken place in various fields with the rapid development of science and technology. In the field of education, the students' interest in learning is obviously improved because of the application of multimedia technology in the teaching of classroom. However, the application of multimedia technology is not limited to the literacy class. The application of multimedia technology in walking race teaching is a good example which completely change the old teaching model that teacher give demonstration to students' imitating, roundly stimulate the various organs of students, enrich the way of walking race teaching and improve teaching results. But there are still some problems that require attention for the application of multimedia technology in the practical walking race teaching. It is the significance of the research really carrying out the integration of multimedia technology and walking race teaching. It can help to fully make use of this technology paying more attention to the teaching details.
\end{abstract}

\section{Problems Existing in the Current Walking Race Teaching}

\section{Paying More Attention to Practice While Ignoring Theory}

China has a long history of five thousand years, walking race is a representative of the traditional sport activities in China. Since the establishment of People's Republic of China, the cause of education in our country has get remarkable development with the efforts of people generation after generation. It was from then that walking race teaching had been an indispensable activity in the physical education. With the constant promotion of walking race, there are more and more walking race enthusiasts, many teenagers join the team of studying walking race routine. At present, many schools offer walking race course from university to primary school. But there are still many problems in walking race teaching of basic level because of the lack of targeted guidance. Many teachers pay too much attention to practice and ignore the theory when they are explaining this course to students, and even in many cases there is no complete teaching plans that make the process of practice to be disorganized. walking race teaching should be carried out with walking race morality as beginning and gradually deepened. The works should be carried out in the first three weeks of teaching plan of five element boxing are listed in the table below by the author. If there is no good work in the aspect of theory, walking race will finally become "setting-up exercise to music" with another form because of the blind imitation of students. Because there is no way of learning the creams of walking race for this kind of "flourish". In fact, the misunderstanding of teachers in walking race teaching is the reason of this problem that it is considered by teachers that walking race is a course to which more attention should be paid and too much explains for 
theoretical knowledge just affect the students' learning enthusiasm. walking race is about "External and internal cultivation" whose current theory is formed according to the inheritance and improvement of people generation after generation. So the theory of walking race teaching is the foundation, and it not only violate the principle of walking race teaching but also affect the understanding and mastering of movements for students abandoning the theory of walking race teaching. Single explains for movements and heavy practice can not ensure good quality of teaching.

Early teaching plan of five element boxing teaching

\begin{tabular}{|l|l|l|}
\hline Week & Content of Courses & Learning Goals \\
\hline the First & $\begin{array}{l}\text { 1. What are walking race and } \\
\text { walking race morality? } \\
\text { 2. Why all classroom rules are } \\
\text { followed? } \\
\text { 3.Learning the basic hand shapes } \\
\text { and movements. }\end{array}$ & $\begin{array}{l}\text { 1. Provide conventional education } \\
\text { of walking race for students } \\
\text { standard basic movements. }\end{array}$ \\
\hline $\begin{array}{l}\text { the Second } \\
\text { Week }\end{array}$ & $\begin{array}{l}\text { 1. Learning kick front, kick side, } \\
\text { internal coordination, kick swing } \\
\text { outward and leg kicking. }\end{array}$ & $\begin{array}{l}\text { 1. Reinforcing the learning contents } \\
\text { of last week. } \\
\text { 2. Mastering the basic kicks. }\end{array}$ \\
\hline $\begin{array}{l}\text { the Third } \\
\text { Week }\end{array}$ & $\begin{array}{l}\text { 1. Practicing splits and bend } \\
\text { backward into a bridge for } \\
\text { flexibility. Improving the flexibility of } \\
\text { 2. Having a basic understanding of } \\
\text { five element boxing. }\end{array}$ & $\begin{array}{l}\text { 1. Itents. } \\
\text { studen }\end{array}$ \\
\hline
\end{tabular}

\section{Single Teaching Model}

At present, some people concerned are always popularizing walking race teaching through various means, but the teaching model of walking race teaching of basic level that "teachers give demonstration for students' imitation" is not broken. The following is the basic contents of walking race teaching. Chart is the only media for assisting teaching in most of schools. Static pictures are not good for the understanding of students for movements. Some schools purchase multimedia equipment, but the equipment is rarely used in the classroom. In addition, the site limitation of practical course in walking race teaching make the multimedia equipment in the classroom to loss its function. A lot of times the teacher play walking race teaching film with multimedia equipment in order to stimulate the learning interest of students. However, the current simple teaching model has completely limit the mastering of the connotation of walking race sport for students. We must face with these problems if we want to change the status of walking race teaching and improve the teaching results with the help of multimedia technology. 
Diagram of classification of the contents of walking race teaching at the present stage

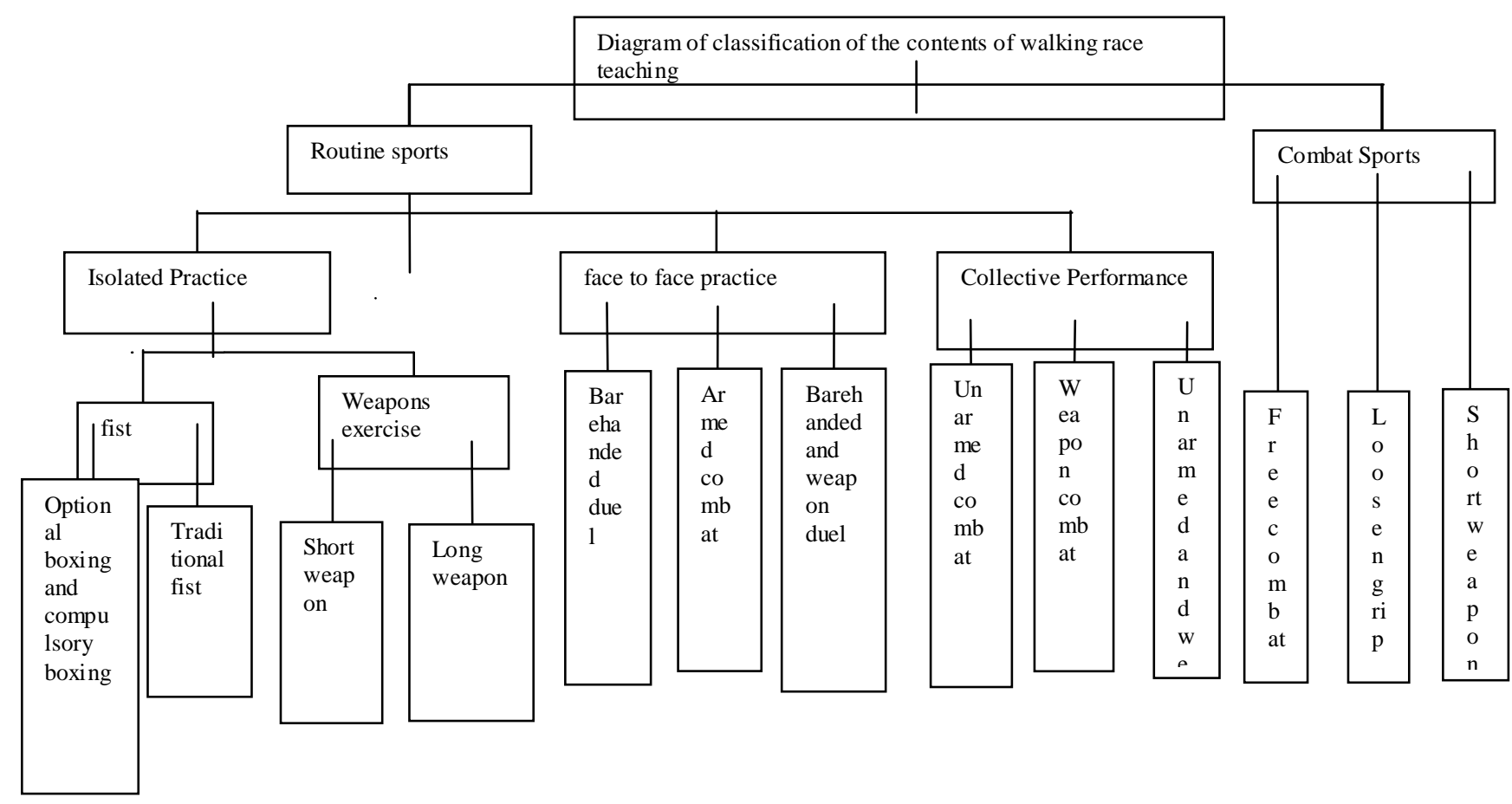

\section{Summary of Characteristics of Walking Race Movements}

In fact, walking race is a kind of sport with relatively high difficulty. Most of the technical movements has no periodicity and regularity, and almost all the technical movements include the contents such as direction, stance structure, route, will and spirit and verve. In addition, the changes of quick-slow, strong-soft and false-true between different movements increase the difficulty of walking race movements. So both the learning of walking race and walking race teaching are the processes from inside to outside, and the qualitative leap of walking race teaching must require the specialized teaching methods and means. In addition, the students should experience the coordination of walking race movements and coordination between offense and defense with practice as the starting point. The good results can not be got with the simple explaining for movements. Here, it should be emphasized that teachers should pay more attention to the risk of walking race movements in order to provide an enough safe environment for students.

\section{Problems to Which More Attention Should be Paid Existing in the Application of Multimedia Technology in Walking Race Teaching}

\section{The Choice and Make of Multimedia Materials}

Firstly, the choice and make of multimedia materials should be carried out with the teaching goals and teaching results required as the starting point to ensure that the materials chose can attract students' attention and stimulate the learning interest of students. However, teachers should seriously research type of multimedia materials and teaching material, combine both of them and make the appropriate arrangement for multimedia materials in a session to ensure the reasonable classroom structure of walking race teaching. It should be ensured in the process of making multimedia materials that multimedia materials must keep to the point and the picture quality must be clear in order to ensure the later learning quality of students. Of course, the explains and guidance of walking race teachers still be the main part in the later teaching, 
multimedia materials just play a subsidiary role in the later teaching, there should be a clear understanding of this aspect in walking race teaching.

\section{The Accurate Understanding of Teachers for Multimedia Materials}

Walking race teachers must have accurate understanding for multimedia materials to provide guidance to students for carefully observing the important contents and provide targeted answers to students for the questions proposed in the process of observing by the students when students are organized to observe multimedia materials. Specifically, the way can be tried that some questions are proposed to be tentatively answered by students before observing, then the later observing will become a progress of reflection. Teachers also can try to make explains in the process of observing for students. But personally, author is used to make explains of the important contents for students in the process of observing in order to keep students' attention to the contents of materials and avoid the ignoring of important contents caused by the blind watching fun for some students.

\section{Trying to Prepare Class with Computer}

Multimedia technology can be applied not only in the classroom teaching but also in the pre-preparation period of teaching in which teachers can prepare class with computer in order to reduce the work amount of teachers. From another point, it is the significance of the application of multimedia technology in walking race teaching that a large number of video materials are needed as reference in the current walking race teaching. However, for the collecting of materials, fully making use of advantages of internet is a good idea. All the walking race teachers should collectively collect materials and form their own databases which can help getting twice result with half effort in the later application of multimedia technology in walking race teaching.

\section{The Specific Process of Application of Multimedia Technology in Walking Race Teaching}

\section{Theoretical Teaching}

The explain of theoretical knowledge is the strong support of walking race teaching. Students can learn nothing but mere form without good work in this aspect. But the explain of theoretical knowledge is boring for most of students. The teaching results can not be ensured if students are not interested in this part of contents. It is pointed out by educationalists concerned that the novelty and interest of teaching model can stimulate the learning interest of students and meet their curiosity. This view bring new thought for the explain of theoretical knowledge in walking race teaching that teachers can try to create materials with important or difficult knowledge with voice, words, pictures and videos with the help of multimedia software and create man-machine interactive pages in order to exactly express the contents should be explained. On the other hand, the illustrated teaching model can fully stimulate many organs of students. In addition, dynamic explain can help students to strengthen their understanding for theoretical knowledge. In this case, the situation is changed that some students are not interested in the theoretical knowledge and have bad results of practice course in the past walking race teaching.

\section{Practice Teaching}

It is determined by the particularity of walking race sport that the good results of students require intuitive demonstration in practice teaching. But the site is limited, interference factors are gradually increasing with the increasing of the number of students that bring higher requests to the demonstration of walking race teaching. In practical teaching process, it can not be ensured that all students can easily see the main points of movements if teacher give demonstration on a fixed position. So it is often happened that teacher need change position for many times for explaining a movement in classroom that not only waste time but also be not a small challenge for the physical strength of teacher. In addition, some walking race movements 
with higher difficulty can not be demonstrated and be kept for a wile or be demonstrated with low speed by teacher in a short time that is the reason of that students can not mastering the essence of some movements. The problem of wasting time because of repeated demonstration is solved if courseware with the teaching contents is made with the help of multimedia technology. In this case, teachers will spend more time correcting the movements of students, and the whole teaching efficiency will be substantially improved. In addition, when the movements with high difficulty are explained, the details can be explained in the mean of zooming in of the details for students' accurate mastering. For the relative positions of different movements and the moving trail of body, the global feature of walking race routine is completely presented to the students with the help of push, move and pull of lens. So multimedia technology is a promoter of the improvement of practical walking race teaching.

\section{Walking Race Practice}

For students, the process of learning walking race is a process full of hard practice. Although the first step of learning a new movement is imitation of the new movement, the later generalization, differentiation, consolidation and automatization are the results of practice. Practice can integrate the walking race movements until the movements become the automatic responses of themselves. In addition, in the first period of imitation, the feeling of students for time and space is general, the specific expression of this situation are disconnected movements and more mistakes. According to the past teaching model, the teacher must give guidance to students according to his teaching experience and understanding for this movement at this time, but most of students do not know what is the root of the problem because of the lack of the general perception for the movement should be done. At this time, if the process of practice of students can be recorded with the help of multimedia technology, and comparison between the materials recorded and the right movements is carried out, or the explain of details is given by the teacher, students must can recognize their own limitations and know their diligent direction. That can provide strong help for them to form the correct technical movements and automate the the learning contents.

\begin{tabular}{|c|c|c|c|c|c|c|c|c|c|}
\hline \multicolumn{2}{|c|}{ Teaching Content } & \multicolumn{2}{|c|}{ Teaching Method } & \multicolumn{4}{|c|}{ Hours } & \multicolumn{2}{|c|}{ Completeness } \\
\hline \multirow[t]{2}{*}{$\begin{array}{l}\text { Basic } \\
\text { skills and } \\
\text { movement } \\
\mathrm{s}\end{array}$} & $\begin{array}{l}13 \\
\text { Undergradu } \\
\text { ate }\end{array}$ & $\begin{array}{l}14 \\
\text { Undergrad } \\
\text { uate }\end{array}$ & $\begin{array}{l}15 \\
\text { Undergrad } \\
\text { uate }\end{array}$ & $\begin{array}{l}13 \\
\text { Underg } \\
\text { raduate }\end{array}$ & $\begin{array}{l}14 \\
\text { Under } \\
\text { gradu } \\
\text { ate }\end{array}$ & $\begin{array}{l}15 \\
\text { Underg } \\
\text { raduate }\end{array}$ & $\begin{array}{l}13 \\
\text { Underg } \\
\text { raduate }\end{array}$ & $\begin{array}{l}14 \\
\text { Underg } \\
\text { raduate }\end{array}$ & $\begin{array}{l}15 \\
\text { Underg } \\
\text { raduate }\end{array}$ \\
\hline & $\begin{array}{l}\text { Traditional } \\
\text { Pattern }\end{array}$ & $\begin{array}{l}\text { Traditiona } \\
1 \text { Media }\end{array}$ & $\begin{array}{l}\text { Multimedi } \\
\text { a Teaching }\end{array}$ & 4 & 4 & 4 & $\begin{array}{l}\text { Mediu } \\
\mathrm{m}\end{array}$ & $\begin{array}{l}\text { Mediu } \\
\mathrm{m}\end{array}$ & Good \\
\hline $\begin{array}{l}\text { Five Step } \\
\text { Boxing }\end{array}$ & $\begin{array}{l}\text { Traditional } \\
\text { Pattern }\end{array}$ & $\begin{array}{l}\text { Traditiona } \\
1 \text { Media }\end{array}$ & $\begin{array}{l}\text { Multimedi } \\
\text { a Teaching }\end{array}$ & 2 & 2 & 2 & Good & Good & Good \\
\hline $\begin{array}{l}\text { Juvenile } \\
\text { Boxing }\end{array}$ & $\begin{array}{l}\text { Traditional } \\
\text { Pattern }\end{array}$ & $\begin{array}{l}\text { Traditiona } \\
1 \text { Media }\end{array}$ & $\begin{array}{l}\text { Multimedi } \\
\text { a Teaching }\end{array}$ & 4 & 4 & 2 & $\begin{array}{l}\text { Mediu } \\
\mathrm{m}\end{array}$ & Good & $\begin{array}{l}\text { Excelle } \\
\text { nt }\end{array}$ \\
\hline $\begin{array}{l}\text { walking } \\
\text { race } \\
\text { Exercise }\end{array}$ & $\begin{array}{l}\text { Traditional } \\
\text { Pattern }\end{array}$ & $\begin{array}{l}\text { Traditiona } \\
1 \text { Media }\end{array}$ & $\begin{array}{l}\text { Multimedi } \\
\text { a Teaching }\end{array}$ & 4 & 4 & 2 & $\begin{array}{l}\text { Mediu } \\
\mathrm{m}\end{array}$ & $\begin{array}{l}\text { Mediu } \\
\mathrm{m}\end{array}$ & Good \\
\hline \multirow[b]{2}{*}{$\begin{array}{l}\text { Theoretica } \\
1 \\
\text { Knowledg } \\
\mathrm{e} \text { of } \\
\text { Simplified } \\
\text { Taijiquan }\end{array}$} & $\begin{array}{l}\text { Traditional } \\
\text { Pattern }\end{array}$ & $\begin{array}{l}\text { Traditiona } \\
1 \text { Media }\end{array}$ & $\begin{array}{l}\text { Multimedi } \\
\text { a Teaching }\end{array}$ & 12 & 10 & 8 & Good & Good & $\begin{array}{l}\text { Excelle } \\
\text { nt }\end{array}$ \\
\hline & $\begin{array}{l}\text { Traditional } \\
\text { Pattern }\end{array}$ & $\begin{array}{l}\text { Traditiona } \\
1 \text { Media }\end{array}$ & $\begin{array}{l}\text { Multimedi } \\
\text { a Teaching }\end{array}$ & 4 & 3 & 2 & $\begin{array}{l}\text { Mediu } \\
\mathrm{m}\end{array}$ & Good & $\begin{array}{l}\text { Excelle } \\
\text { nt }\end{array}$ \\
\hline
\end{tabular}

The above is the statistics (with academic year as unit) for the application of multimedia technology in walking race teaching produced by the author. From the above table, it can be seen that teaching quality is obviously improved when multimedia technology is applied in 
theoretical theory, basic movements and systematic walking race movements. So the popularization and application of multimedia technology in walking race teaching should be encouraged and supported.

\section{Reference}

[1] Shi, J. H., \& Hong, L. Explore the effective use of multimedia technology in college physics teaching. Energy Procedia, 17(2012), 1897-1900.

[2] Cohen, M., \& Freidus, H. Examining the value of technology in creating and assessing narrative pedagogy in teacher education. Journal of Athletic Training, 37(2002), S213S219.

[3] Rifà-Valls, M. Experimenting with visual storytelling in students' portfolios: narratives of visual pedagogy for pre-service teacher education.International Journal of Art \& Design Education, 30 (2011), 293-306.

[4] Zeichner, Ken, and K. Y. Liu. A Critical Analysis of Reflection as a Goal for Teacher Education. Handbook of Reflection and Reflective Inquiry. Springer US, 2010:67-84.

[5] Kitchenham, Andrew, and C. Chasteauneuf. "An Application of Mezirow's Critical Reflection Theory to Electronic Portfolios." Journal of Transformative Education 7.7(2009):230-244.

[6] Stansberry, Susan L, and A. D. Kymes. "Transformative Learning through." Journal of Adolescent \& Adult Literacy 50.6(2007):488-496.

[7] Greenhill, J, and A. N. Poncelet. "Transformative learning through longitudinal integrated clerkships. " Medical Education 47.4(2013):336-9.

[9] Xie, Xiao Liang. "Study on Development and Management of Teaching Resources and Video Multimedia Technology Environment."Southwestern Historical Quarterly 641.641(1994):311-8.

[10] Zhang, Jun Hua, et al. "Study on Resource Construction and Management of Multimedia Network Teaching." Advanced Materials Research 756-759.6(2013):800-803. 